\title{
TEACHER'S INSTRUCTION IN THE REFLECTION PHASE OF THE PROBLEM SOLVING PROCESS
}

\section{Meira Koponen}

University of Helsinki • meira.koponen@ helsinki.fi

\begin{abstract}
Mathematical problem solving has a key part in developing students' mathematical thinking. Yet in the Finnish primary school classrooms mathematics lessons are very traditional and have little room for problem solving and mathematical discussions. Although problem solving has been a part of the Finnish curriculum for a few decades, it is the teachers who seem to choose not to include problem solving in the classroom on a regular basis. In this article I take a look at three Finnish fifth grade teachers who took part in a study on problem solving. They each incorporated problem solving in their mathematics lessons approximately once a month, and in this study I focused on one of the problems - an open problem called "The Labyrinth". In each lesson I chose to focus on the teachers' instruction in the reflection phase of the problem solving process. When instructing individual students in the reflection phase and during whole-classroom discussions, the teacher has an opportunity to point out the important parts of the problem solving process, help the students make connections and recall key moments of the process. In the reflection phase there is an opportunity to reflect, review and analyze one's solutions and make generalizations. In the Labyrinth problem the teacher's own understanding of the solution was an important factor during the instruction and the whole-classroom discussion. If the teacher's instruction was purely led by the students' own discoveries and insights, some important points were left unexplored. The teacher can even lead the students to the wrong direction, if he or she hasn't carefully thought through the solution of the problem beforehand. The problem solving lesson is not just about finding a suitable problem and presenting it to the students, but guiding the students in the process.
\end{abstract}

\section{Preface}

Problem solving has been a part of the Finnish curriculum for a couple of decades but still it has not found its place in the classroom reality (Pehkonen, Hannula \& Björkqvist 2007, 121). While problem solving, and especially open problems, is thought to improve mathematical thinking and creativity (Mason, Burton \& Stacey 1985; Pehkonen 2001), it seems that the Finnish mathematics lessons are still very traditional and have little room for lively mathematical discussions (Perkkilä \& Lehtelä 2007, 77). Pehkonen $(2007,129)$ argues that teachers might find problem solving too time-consuming and difficult to be implemented in their classrooms. However it is the teacher's task to try to improve his or her students' mathematical thinking and problem solving skills, and to implement problem solving into the mathematics lessons. This is why I focus on the teacher when looking at problem solving lessons.

Choosing a suitable problem and understanding the nature of it is an important part of a problem solving lesson (Chapman 2013, 1-2). Through carefully planned instruction the teacher can guide the problem solving process and help the students make important connections themselves. There is a fine line between enough guidance and too much 
guidance - when students find the answers themselves and when the teacher reveals them for them. The reflection phase of the problem solving process was selected to be the focus on this study. It is a phase that is too often overlooked in school mathematics as students are used to writing down the answers and moving on to the next problems (Mason 1985; Hähkiöniemi \& al. 2012). According to Shimizu (1999, 110-111) reflecting the solution and the strategies that led to the solution are a key part of the problem solving lesson. Reflections can bring up new insights about the solution which can be applied into practice later on (Boud, Keogh \& Walker, 1985). The whole-classroom discussion after the solution has been found is an important opportunity for the students to share strategies, insights and observations and engage in a mathematical discussion. When the students' observations and ideas are brought together the class can try to find the underlying mathematical idea behind the problem itself. Reflecting and analyzing one's own solution can deepen the student's mathematical thinking and improve his problem solving skills (Mason \& al. 1985), thus the reflection phase of the problem solving process shouldn't be overlooked.

The focus of this study was to take a closer look of three Finnish fifth grade teachers and their instruction of the reflection phase during a problem solving lesson. The goal was to analyze the whole-classroom discussions as well as individual or small group instruction given by the teachers.

\section{Theoretical background}

The problem solving process includes not only the solving of a problem, but also other phases of thinking described in various models depicting problem solving processes. Perhaps one of the most well-known problem solving models is Pólya's 4-step model (1945), which includes such steps as understanding the problem, devising a plan, carrying out the plan and looking back at the solution. Other models of problem solving also try to bring light to the thought processes of a student involved in solving a problem (i.e. Dewey 1910, Pólya 1945, Mason \& al. 1985, Schoenfeld 1985, Hähkiöniemi, Leppäaho \& Francisco 2012).

For this study I was most concerned with the final phase of the problem solving process, the phase where the students reflect on their solutions and strategies after they have already found at least one solution to the problem. Taking a closer look on the problem solving models of Pólya (1945) and Mason (1985), I tried to define the reflection phase of the problem solving process. Pólya $(1945,14-15)$ describes the final phase of the process as the 'looking back'-phase. It is where the students look back on their actions during the problem solving process and make observations, analyze mistakes and connect the solution to a larger mathematical context. Mason (1985) views the problem solving as a cyclic process where the solver moves back and forth, perhaps getting stuck and having to take steps back along the way. After the solution is found, it is important to review the process (Mason \& al. 1985, 28). The review-phase is divided into three segments: checking the 
Table 1 The student's reflection phase and example questions (Pólya 1945, Mason 1985)

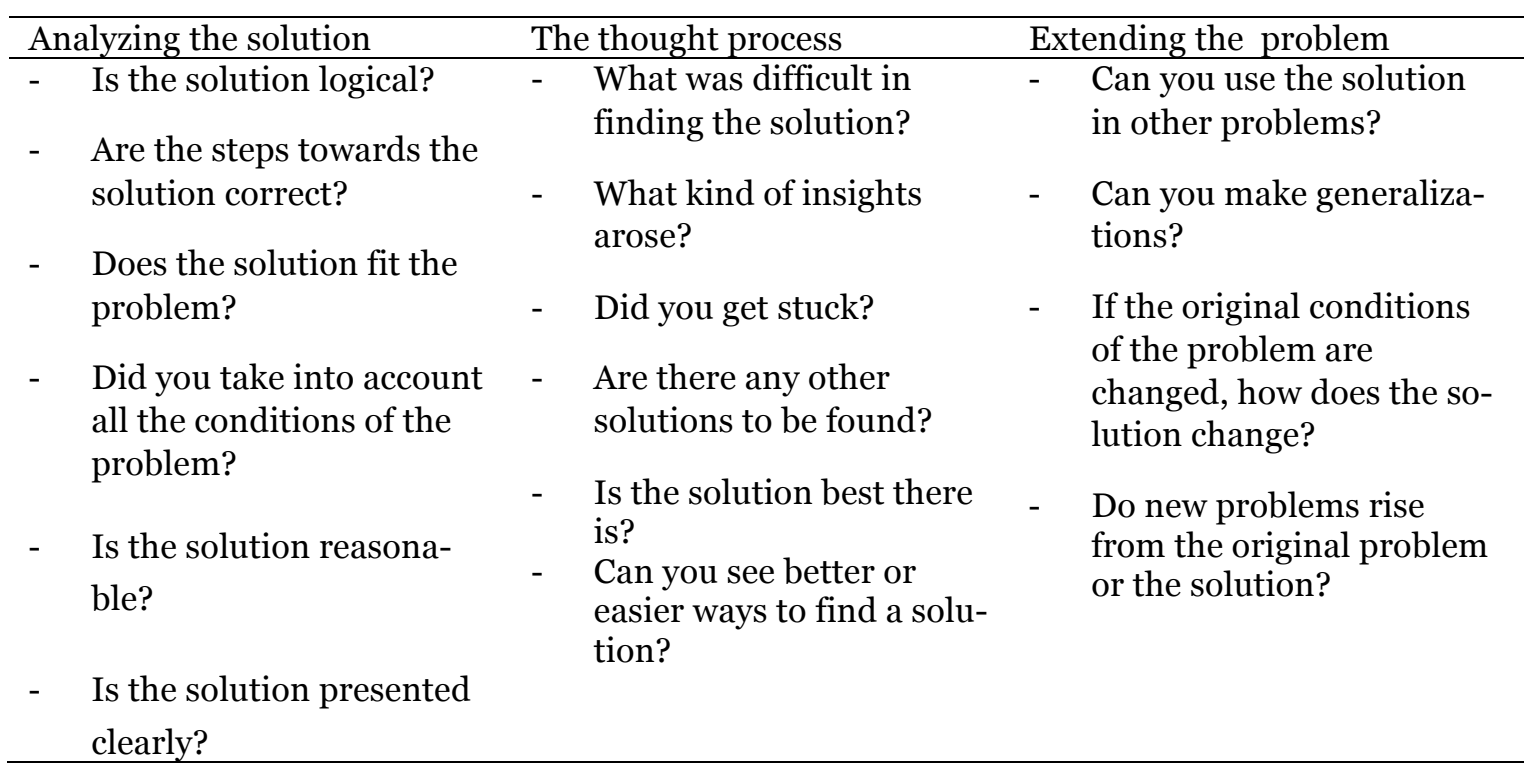

answer, reflecting the overall solution and the strategies and key moments during it, and generalizing the solution. Both Pólya (1945) and Mason (1985) offer a number of questions to be asked in the reflection of the problem solving process. In table 1 the student's reflection phase has been divided into three categories with examples of what one might consider during the last phase.

As students might not be used to reflecting on the solution without guidance, the questions above are also useful for the teacher's instruction during the lesson.

Teaching problem solving is not a simple task. The problem solving process is connected to each individual solver - a problem for one student can merely be a routine task for another (Haapasalo 1998, 17). As studies have shown (Schoenfeld 1992, 52) teaching just individual problem solving strategies yield disappointing results. The final classroom discussion might in fact be a good place to foster and model problem solving skills in general.

In addition to the reflective questions in table 1, I took into consideration some general aspects of successful problem solving as described in previous studies (i.e. Lester \& Kehle 2003, Lesh \& Zawojewski 2007; Schoenfeld 1985). Fostering successful problem solvers in the classroom extends beyond the content knowledge, to metacognitive skills and attitudes towards problem solving and mathematics, for instance. Students should be able to not only handle the mathematics of the problem, but regulate, assess and control their attempts at solving the problem, and have a positive attitude towards problem solving as well as trusting themselves as a problem solvers (Lester \& Kehle 2003, 507).

In table 2 I gathered the reflective questions from table 1 and re-arranged them into two categories: the mathematics and the mathematical context of the problem and the problem 
Table 2 Categories for instructing the student's reflecting phase and the whole-classroom discussion (Lester \& Kehle 2003, Schroeder \& Lester 1989, Schoenfeld 1985, Lesh \& Zawojewski 2007)

\begin{tabular}{|c|c|c|}
\hline Categories & Sub-categories & Examples \\
\hline \multirow{5}{*}{$\begin{array}{l}\text { The "mathematics" of the } \\
\text { problem and the } \\
\text { mathematical context }\end{array}$} & $\begin{array}{l}\text { a) The mathematics: "Teach- } \\
\text { ing via problem solving" }\end{array}$ & $\begin{array}{l}\text { Generalizing the problem \& } \\
\text { solution }\end{array}$ \\
\hline & $\begin{array}{l}\text { b) Considering the } \\
\text { mathematical context of }\end{array}$ & $\begin{array}{l}\text { Making connections between } \\
\text { problems }\end{array}$ \\
\hline & the problem \& solution & Understanding the \\
\hline & $\begin{array}{l}\text { c) Conventions of the } \\
\text { discipline }\end{array}$ & $\begin{array}{l}\text { mathematical context of each } \\
\text { problem and choosing the } \\
\text { right problem for the } \\
\text { students }\end{array}$ \\
\hline & & $\begin{array}{l}\text { Mathematical conventions: } \\
\text { presenting the solution }\end{array}$ \\
\hline \multirow[t]{5}{*}{ Problem-solving strategies } & a) Metacognitive strategies & $\begin{array}{l}\text { Self-regulating and } \\
\text { controlling one's thinking }\end{array}$ \\
\hline & D) Heuristics & Using strategic thinking \\
\hline & & $\begin{array}{l}\text { Being aware of one's thought } \\
\text { processes }\end{array}$ \\
\hline & & $\begin{array}{l}\text { Using pre-learned problem- } \\
\text { solving strategies }\end{array}$ \\
\hline & & $\begin{array}{l}\text { Comparing different } \\
\text { strategies and knowing } \\
\text { which one to use }\end{array}$ \\
\hline \multirow{5}{*}{$\begin{array}{l}\text { Student's attitude and beliefs } \\
\text { towards mathematics \& } \\
\text { problem-solving }\end{array}$} & \multirow{2}{*}{$\begin{array}{l}\text { a) Attitude to self in relation to } \\
\text { mathematics and problem- } \\
\text { solving }\end{array}$} & $\begin{array}{l}\text { Minimizing negative } \\
\text { attitudes and beliefs }\end{array}$ \\
\hline & & Creating positive attitudes \\
\hline & \multirow{2}{*}{$\begin{array}{l}\text { b) Attitude to the mathematical } \\
\text { context }\end{array}$} & \\
\hline & & Understanding mistakes as a \\
\hline & $\begin{array}{l}\text { c) Attitude to mathematics as a } \\
\text { discipline }\end{array}$ & process \\
\hline
\end{tabular}

solving strategies, which was divided into two sub-categories (metacognitive strategies, i.e. the habits of mind, and the heuristic strategies). A third category, which was concerned with the student's attitude and motivation, was also added. In the whole-classroom discussion there is a good opportunity for the teacher and classroom to further explore the topics suggested in table 2.

In teaching problem solving the teacher should also understand that problem solving is not a straightforward process and successful instruction and results are not always so easily 
replicated in the classrooms. It is in the nature of problem solving itself to have an aspect of creativity and insights (Mason \& al. 1985, 127).

\section{The aim of the study and the analysis of the data}

This study was a part of a larger study conducted by a research team in the University of Helsinki during 2010-2013 and funded by the Academy of Finland. Teachers from Finland were given problems to solve in their mathematics lessons approximately once a month during the school year and the students and their teachers were followed from grade 3 to grade 5 . The goal of the larger project was to study the effects of problem solving on the mathematical thinking, and the original data was collected through interviews, student solutions, videotaped lessons and observations.

In this study I chose to analyze the lessons of three Finnish primary school teachers who had been part of the study from the beginning. The data consisted of videotaped lessons and was collected in early 2013, so the problem taught was the seventeenth problem altogether. The students, fifth-graders during the problem in question, had started solving problems in the project from grade 3 under the instruction of their own teacher. Thus it was expected beforehand that the teachers and their students would be somewhat experienced in problem solving already. The problem, the Labyrinth, was also selected because it does not have one easy answer, which could be shown to the students during the wholeclassroom discussion. Rather the problem explores new mathematical ideas for fifthgraders that the teacher needs to carefully consider during and before the instruction.

The teachers were primary school teachers, who in Finland have a master's degree in education. The teachers in question did not have a degree in mathematics, however they had volunteered in the 3-year-project, so they had some interest in problem solving and mathematics teaching in general. They all had over 10 years of teaching experience. During the project they met with the original research team before and after the problem solving lessons and they had the opportunity to talk with the researchers and discuss problem solving with them. They were given the problem and a worksheet for the students but not ready-made lesson plans or the solutions to the problem. The teachers were given the power to choose themselves in which way they used the problem in their lesson.

The research question of this study was:

- How do Finnish fifth grade teachers instruct their students during the reflection phase of the problem solving process including the whole-classroom discussion?

In trying to answer the research question I used the video recordings of the three 45minute lessons. The videos were transcribed for further analysis. I used the literature presented in chapter 2 to carefully identify the reflection phase from the data. I organized the teachers' comments during the reflection phase into sub-categories presented in table 2. In addition, I looked for non-verbal instruction and other comments that would be outside the categories that I had identified. I looked for continuity in the instruction during the 
whole lesson - whether the teacher had a clear goal in the overall lesson that would culminate in the whole-classroom discussion at the end of the lesson and whether the teacher systematically worked to push students towards that goal.

\section{The labyrinth problem}

The teachers and their students were presented with the following problem (see Figure 1).

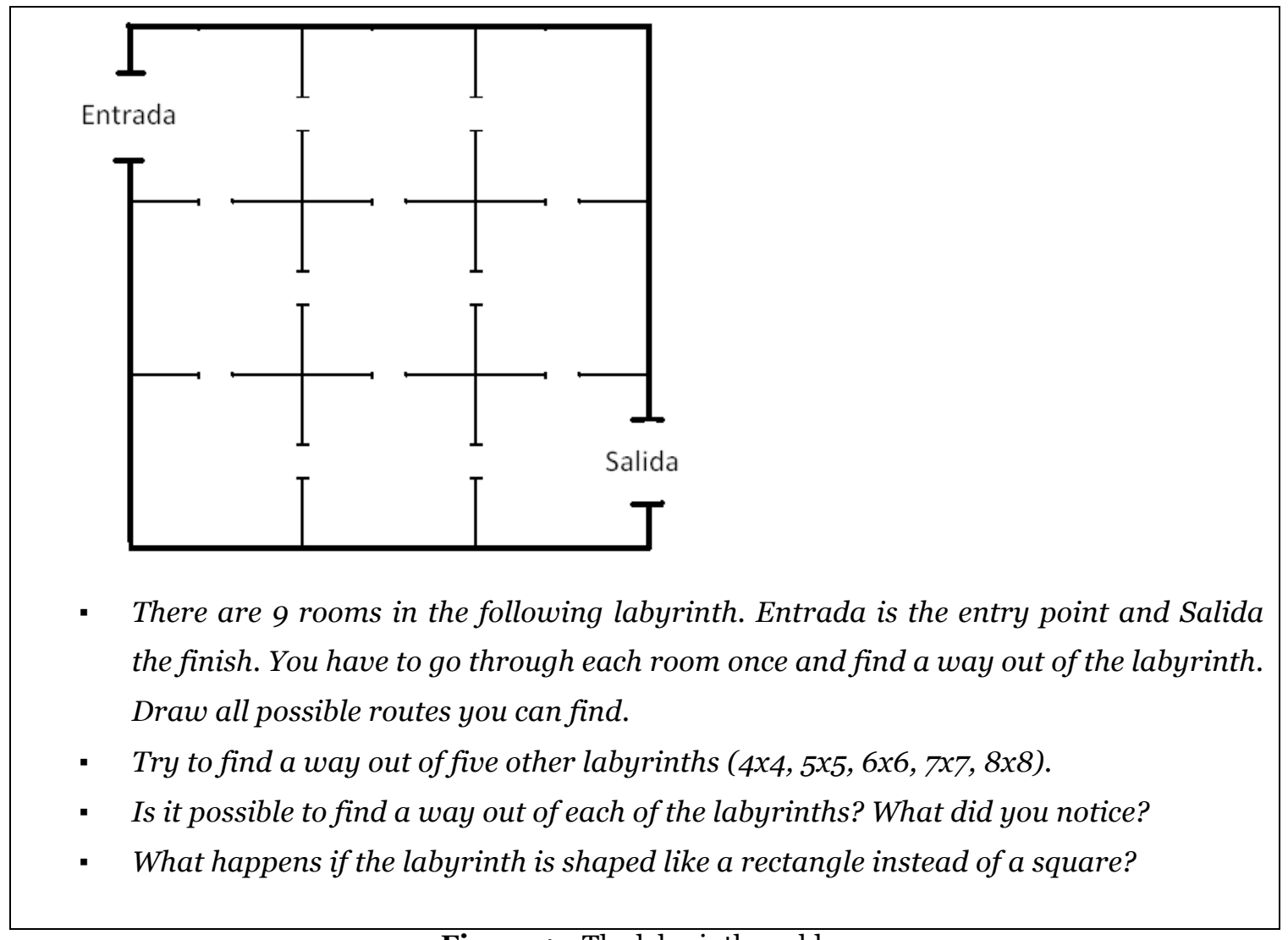

Figure 1 The labyrinth problem

In this problem the fifth-graders are not expected to find an exact mathematical solution to the problem nor is it expected that the teachers would present one for them. The teachers were given the problem but not lesson plans or solutions to the problem.

In the Labyrinth problem there are several mathematical observations to be made and brought up in the whole-classroom discussion:

- There are no solutions to some of the labyrinths. This is an important observation to be made by the students. Some mathematical problems are unsolvable, which might be a new notion to fifth-graders as this is not often explored in mathematics workbooks.

- The teacher can try to guide the students to systematically try certain approaches to the labyrinths and bring them later up in the classroom discussion: is there a systematic way to work through the possibilities.

- The number of solutions increases as the labyrinth grows. 
- The students should be able to observe the labyrinths and make a hypothesis on what determines the solvability of the labyrinth. They should be able to formulate a rule that the impossible labyrinths are the ones with even number of rooms on each side and solvable ones are the ones with odd number of rooms on each side.

- This rule, however, does not apply to the rectangular labyrinth. It is enough that only one of the sides has an odd number of rooms. This new rule applies both to the rectangular and square shaped labyrinths.

The problem gives an opportunity to gather the students' individual observations systematically and guide them to making the key observations about the labyrinths. They can also be asked to reason and justify their thoughts, even if they cannot mathematically prove their solutions at this time. The rule for the square labyrinths and the rule for the rectangular ones can be compared and the students can contemplate the importance of modifying mathematical rules to apply in other contexts as well.

\section{$5 \quad$ Findings}

The three teachers, named here Anna, Helena and Eva, had a similar structure in their lessons: first the introduction of the problem, then working on the problem in pairs or in small groups, during which the three teachers instructed the individual students on their solutions, and the final whole-classroom discussion, which was held only by Anna and Eva. All teachers used the same worksheet with their students. I will look at each teacher's instruction individually. Summary of the teacher's instructions can be found in Table 3.

\subsection{Anna}

\section{Mathematical context of the problem}

Anna's students seemed to be experienced problem solvers as it was expected at this point of the research project. Although the exact mathematical solution is too difficult for fifth grade students, Anna encouraged them to make observations, formulate a hypothesis and test it in their own, larger labyrinths. Because her students figured out quickly that some labyrinths were unsolvable, the class had the most time to keep working on the problem.

Anna: Now that you're figuring out the solutions, I want you to think why some of the labyrinths don't have a way out. Why this one does, and this one doesn't?

Anna: You've presented a theory here: odd ones are the impossible ones. You have to test if this is really true or not. You've made a claim. Now you have to prove it. Write down your reasoning why you think it's the way you said it is.

Although many of the students came to the same conclusions about odd and even labyrinths, not all of the students succeeded in the problem solving.

Anna: Now you've heard other students talk about odd and even number of rooms. Do you think there's an odd or even number of rooms in this labyrinth?

Student: I don't know. 
Anna: (Counts the rooms and points to each room... Doesn't count all of the rooms)

How many rooms are there?

Student: Sixteen. (Incorrect answer)

Anna: No, I didn't count them to the end. Even number means that you can divide it in two. If you put a pencil in the middle of the labyrinth, do you think there's the same number of rooms on each side?

Student: No?

Anna: Well, yes there is. There is an even number of rooms in this labyrinth. So... If there's an even number of rooms, then...?

Student: ...

Anna: Do you think you can get out of this labyrinth or not?

Student: Yes?

Anna: -- You could find a way out from the odd ones... So... Apparently you can't find a way out from this one, right?

Student: (Nods)

Anna: Well... Try to find other solutions to these two labyrinths.

For some of the students the labyrinth problem might have been too difficult or other factors might have made it hard for the student to solve the problem.

Table 3 Summary of the three teachers

\begin{tabular}{|c|c|c|}
\hline Anna & Helena & Eva \\
\hline $\begin{array}{l}\text { instructed the students } \\
\text { to making observations, } \\
\text { formulating a hypothesis } \\
\text { and testing it in square } \\
\text { labyrinths. } \\
\text { extended the solution to } \\
\text { rectangular labyrinths. } \\
\text { - Encouraged the students } \\
\text { to creating new prob- } \\
\text { lems. } \\
\text { instructed the students } \\
\text { to systematically try sim- } \\
\text { ilar solutions to different } \\
\text { labyrinths and sharing } \\
\text { their techniques with } \\
\text { peers. } \\
\text { had a whole-classroom } \\
\text { discussion where the } \\
\text { rule was stated. }\end{array}$ & 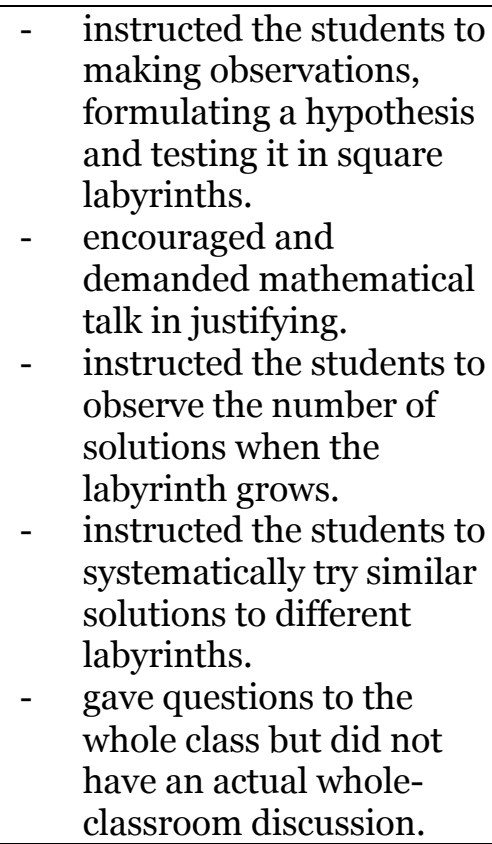 & $\begin{array}{l}\text { - } \quad \text { instructed the students } \\
\text { to finding solutions to } \\
\text { the labyrinths. } \\
\text { - instructed the students } \\
\text { to finding alternative } \\
\text { solutions. } \\
\text { - had a whole-classroom } \\
\text { discussion where the } \\
\text { "right" answers to the } \\
\text { labyrinths were shown. }\end{array}$ \\
\hline
\end{tabular}




\section{The thought process}

Anna's students were resourceful when trying to find the solutions. Some of them asked if it was allowed to use a previously found solution and try it in other labyrinths as well. Systematically trying out similar solutions in all of the labyrinths instead of just trying random solutions was also discussed with all of the students. The students were encouraged to share their techniques with their peers.

Anna: Notice that you can use this solution idea in many ways in the other labyrinths as well.

The students seemed to be quite skilled problem solvers who in most parts started realizing there was something wrong with the impossible labyrinths and moved on to other parts of the problem and did not waste too much time trying different techniques at the unsolvable parts of the problem. Anna gently nodded and approved their ideas guiding them to the next step of the problem solving.

\section{Extending the problem}

It took quite some time for the students to build a rectangular labyrinth where their original rule did not apply, but Anna kept on pushing the students to keep on working until they found one. At the very end of the class such labyrinth was found and tested. The new rule was formulated together with the classroom but the original rule was not modified.

Anna: Hey, last question about this lesson. - Quite a few of you noticed, that the rectangular one where there's an even number of rooms (shows $7 \times 10$ to the students), there's still a way out. Why?

Students: Because it's not a square and there's an even and odd number.

Anna: So when one of the sides has an odd number of rooms, and the other has even number, that's the so called catch here.

New problems also arose while others were still working on generalizing the rule in rectangular labyrinths:

Student: "Teacher? Can I put the door wherever I want it? Does it have to be right here?"

Anna: "Sure, put it anywhere you please. There just have to be two different doors."

The students found solutions easily to the solvable labyrinths and Anna encouraged the students to speak aloud how they found them and whether similar techniques could be transferred to larger labyrinths.

\section{Fostering positive attitudes and atmosphere}

The atmosphere in Anna's classroom was positive and students were encouraged to try, although not all efforts yielded a solution. The students had no problems in expressing their ideas with the class even though they were not always sure about the right answer. Anna tried to acknowledge positively even the attempts that were not successful.

\subsection{Helena}




\section{Mathematical context of the problem}

Helena instructed her individual students to making meaningful observations and the students did find a rule for the solvability of the square labyrinths. She modelled the mathematical speech to the students and also expected them to try and speak mathematically when talking about their hypothesis. By talking like mathematician a teacher can model the ways a mathematician thinks, but controlling too much students own attempts at speaking mathematics can influence negatively students' willingness to even try (Pimm 1987, 42). However, Helena's students didn't seem to be too taken aback when asked to be more accurate in their mathematical speech.

Student: "I know what it is.. Because we think that if you add two to this and two to that then you can solve it... So you add just the "one", odd number to this.

Helena: "You add what, where?"

Student: "One... Square..."

Helena: "Now be precise".

Student: "Row, one row more."--

Helena: "Listen up, if it's vertical, it's a column, if it's horizontal, it's a row. Now

formulate (the rule) by using these terms. - Think, when you say "one", one what?"

The students' rule was not brought up in a whole-classroom discussion and the students did not generalize it in rectangular labyrinths. A whole-classroom discussion could have been a useful place to refine students' arguments and explore larger mathematical context (Shimizu 1999, 110-111).

\section{The thought process}

Helena also instructed the students to focus on the number of solutions to each of the labyrinth. She tried to get the students to make observations from the number of solutions:

Helena: Do you think there is some sense, some system, from which you can reason something? - Now you claimed there's three different solutions to this labyrinth. First you had only two. Now you have three. Now you should think, are there more than three. -You can keep on adjusting the rule. And then, is it possible to find out how many solutions there actually is, for sure?

However the number of routes were not truly explored together. It was only stated together, that there were two possible routes to the smallest labyrinth ( $3 \times 3)$. The students' reasoning was based on their own investigations that two routes were the only ones they could find.

Helena's students also systematically tried already found solutions in the larger labyrinths so the strategies of finding solutions were not entirely random.

\section{Extending the problem}

The extension of rectangular labyrinths was not discussed during the lesson. 


\section{Fostering positive attitudes and atmosphere}

Helena treated the students as "mathematicians" during the lesson. She used a lot of mathematical talk herself and expected her students to try as well. Helena also challenged the students' answers. The students seemed to be quite used to this and did not hesitate when asked to try and formulate more mathematical answers.

\subsection{Eva}

\section{Mathematical context of the problem}

Eva's students failed to find a solution the problem. Despite the positive and encouraging atmosphere and the student's resilience, the impossible labyrinths proved out to be just that - impossible. There seemed to be a false assumption that each and every labyrinth had a solution and the lesson was spent on finding the routes out from the impossible labyrinths. Based on Eva's instruction during the lesson, it seemed that she had not understood or had forgotten that some labyrinth were unsolvable.

Student: Now we got it!

Eva: Yeah? (Comes to check the solution) Okay, so it's four by four -- ...You actually

did it! Good! Really great!

(There are no solutions to the $4 \times 4$ labyrinth)

At one point two students came very close to making a conclusion that there is an error in the worksheet. However this opportunity was not followed up on and Eva instructed the students to move on to the easier labyrinths instead. During the whole-classroom discussion Eva asked some students to come up and show the "right" answers to the labyrinths. However, the mistakes in the solutions were noticed by the other students and pointed out. These observations were dismissed quite easily and Eva suggested some easy corrections to the solutions, but such corrections were not followed through.

Problem solving is not always a success. Even if the problem is left unsolved and the students discard the problem as too difficult or unsolvable, there is still a possibility to learn something (Mason \& al. 1985, 61). After working very hard during the lesson but accomplishing almost nothing, it could have been useful to validate those efforts by pondering the possible reasons why the problem was left unsolved or why parts of it were extremely difficult. Even the modifications that one student group suggested (removing a row of squares) could have been explored further.

\section{The thought process}

There seemed to be little logic in finding the solutions. There were no conversations on systematically trying out different solutions in larger labyrinths. Eva did encourage the students to find alternative solutions to the labyrinths, however she also revealed the solutions quite easily.

Eva: Is there an alternative solutions to this one?

Student: Is this correct? 
Eva: Yeah... But, is there an alternative solution? ...Now you visit this room twice.

Wouldn't it be easier to just go through here and there (shows the route).

Student: Yeah.

\section{Extending the problem}

There was no time for the exploration of the rectangular labyrinths and Eva left that part of the problem to be done at home. She instructed the students to make "chess boards" from the labyrinths and observe the color of the tile in the start and at the finish.

\section{Fostering positive attitudes and atmosphere}

Eva's students showed resilience in the problem solving although they didn't find the answer to the problem. In the whole-classroom discussion they also questioned the answers given to them. Eva was encouraging and sympathetic at their efforts in finding an answer.

\section{Concluding remarks}

There are many aspects of problem solving to consider while instructing the students in their problem solving processes. Problems should not be seen as individual extra tasks separated from the day to day mathematics teaching, but as an important part of teaching mathematics and developing mathematical thinking and problem solving skills. The problems should be seen as tools for reaching a pre-determined goals. (Karp 2009, 130; Chapman 2013, 1-2.) The problem should be chosen with a clear goal in mind and the teacher's instruction should help the students reach the goal, without giving too much away (Chapman 2013, 1-2; Hähkiöniemi \& al. 2012). The whole-classroom discussion is a place to gather student observations together and link them with a larger mathematical context (Shimizu 1999, 110-111).

In this study I focused on the instruction of three Finnish fifth grade teachers. Two of them, Anna and Helena had a clear goal in mind during their lessons. They instructed their students into making observations, formulating a rule which they also tested. They tried to find a systematic way of trying out solutions to the labyrinths. Anna also instructed her students into generalizing the rule. Eva's instruction was quite different. Her students were not successful in finding a solution to the problem. The whole-classroom discussion was also very traditional in Eva's case. She called students on the board to show "the right" answers, which were not truly explored or corrected together.

Anna's students were the fastest problem solvers so Anna had the most time to keep on working with the problem. Helena chose not to generalize the rule, which time wise might have been a good solution: her students focused on the number of solutions to each labyrinth as well as finding the impossible labyrinths. Eva's students worked on the solution until the very end of the lesson where they checked the solutions together and were assigned the homework. Working with open problems in classroom environment can be challenging. Sometimes solutions take more time to unravel and it might be useful for some students to take a break and return to the problem at another time. In Eva's case returning 
to the problem after perhaps trying to solve the homework could lead to more meaningful observations.

Pehkonen $(2007,129)$ has said that teaching problem solving is difficult and timeconsuming. From finding the right problem to making lesson plans and carrying them out, it requires teachers to have both the necessary content knowledge and understanding of the instruction of the problem solving process. It seemed that Anna and Helena had solved the problem beforehand and had a clear objective in mind for the lesson which they then carried out. Eva, on the other hand, probably had not tried solving the problem before the lesson. In her lesson it is quite clear that the teacher's proper instruction can either help or hinder the students' efforts in finding the solution. When the so-called catch of the problem is clear in the teacher's mind, she can carefully guide the students towards the solution. When the students start to formulate a hypothesis that a labyrinth is unsolvable or there is an error in the worksheet, the teacher can either let them pursue their theory or suggest that the students pursue something else altogether.

Understanding the nature of the problem is vital for the instruction during the entire lesson but especially in the reflection phase - it is quite difficult to gather up observations and remarks in a systematic and meaningful way, if one has not understood or decided what the goal of the lesson is. It is also important for the teacher to follow up on students' ideas in the whole-classroom discussion, summing up what was discovered and also giving an opportunity for the students to share their insights with their peers.

It is simply not enough to choose an open problem for the lesson, if the teaching and instructing does not activate the students' thinking processes. When preparing the problem solving lesson the teacher should carefully analyze the problem, the solution and the key points that the students should pick up on, and also keep in mind the problem solving process in general. The teacher should also be prepared to lead a mathematical discussion and value students' questions and ideas, even if they were unexpected. In this study all the teachers were given the same problem to start with and some were more successful than others. With fifth grade students the teacher was not expected to provide an exact mathematical solution to the Labyrinth problem. However, she was expected to know which of the labyrinths were unsolvable and how she could predict the solvability in each of the labyrinths. She also should have been able to generalize the rule. In Eva's case the lack of preparation might have been the reason for the lack of meaningful instruction. Whether this was due to Eva's personal teaching style or some other reason it is impossible to tell without analyzing her other lessons, her lesson plans or interviewing her.

After teaching 17 problem solving lessons over the course of three years, we got a glimpse where the teachers are now. In future research it could be interesting to follow the teachers' instructional development during the project years. Also looking at other problem solving lessons could give more insight into their planning and teaching styles and whether they matter in the success of the problem solving lesson. 


\section{References}

Boud, D., Keogh, R., \& Walker, D. (1985). Reflection: Turning experience into learning. London: Kogan Page.

Dewey, J. (1910). How We Think. Boston, MA: D.C. Heath \& Co..

Chapman, O. (2013). Mathematical-task knowledge for teaching. Journal of Mathematics Teacher Education, 16, 1-6.

Haapasalo, L. (1998). Oppiminen, Tieto \& Ongelmanratkaisu. Joensuu: Medusa Software.

Hähkiöniemi, M., Leppäaho, H., \& Francisco, J. (2012). Model for teacher assisted technology enriched open problem solving. In Bergqvist, T. (Ed.), Learning Problem Solving and Learning Through Problem Solving, proceedings from the 13th ProMath conference (pp. 30-43). Umeå: Umeå university.

Karp, A. (2009). Analyzing and attempting to overcome prospective teachers' difficulties during problem-solving instruction. Journal of Mathematics Teacher Education, 13, 121-140.

Lesh, R. \& Zawojewksi, J. (2007). Problem solving and modeling. In Lester, F, K. (Ed.), Second Handbook of Research of Mathematics Teaching and Learning vol. 2 (763-804). Charlotte, NC: IAP \& National Council of Teachers of Mathematics.

Lester, F. K., \& Kehle, P. E. (2003). From problem-solving to modeling: The evolution of thinking about research on complex mathematical activity. In Lesh, R. \& Doerr, H. (Ed.), Beyond constructivism: Models and modeling perspectives on mathematics problem solving, learning, and teaching (pp. 501-518). Mahwah, NJ: Lawrence Erlbaum Associates.

Mason J., Burton L., \& Stacey K. (1985). Thinking Mathematically. Boston, MA: Addison-Wesley.

Pehkonen, E. (2001). How Do We Understand Problem and Related Concepts? In Pehkonen, E. (Ed.), Problem Solving Around the World. Proceedings of the Topic Study Group 11 (Problem Solving in mathematics Education) at the ICME-9 meeting August 2000 in Japan. Turku: Turun yliopisto.

Pehkonen, E., Hannula, M., \& Björkqvist, O. (2007). Problem solving as a teaching method in mathematics education. In Pehkonen, E., Ahtee, M. \& Lavonen, J. (Ed.), How Finns Learn Mathematics and Science (121-129). Rotterdam: Sense.

Perkkilä, P. \& Lehtelä, P. (2007). Learning environments in mathematics and science. In Pehkonen, E., Ahtee, M., \& Lavonen, J. (Ed.), How Finns Learn Mathematics and Science (69-84). Rotterdam: Sense.

Pimm, D. (1987). Speaking mathematically: Communication in mathematics classrooms. London: Routledge \& Kegan Paul.

Pólya, G. (1945). How to solve it: A new aspect of mathematical method. New Jersey: Princeton University Press.

Pólya, G. (1962). Mathematical discovery: on understanding, learning, and teaching problem solving. Volume 1. New York, NY: Wiley.

Schoenfeld, A. H. (1985). Mathematical Problem Solving. Orlando, FL: Academic Press.

Schoenfeld, A. H. (1992). Learning to think mathematically: Problem solving, metacognition, and sense-making in mathematics. In Grouws, D. (Ed.), Handbook for Research on Mathematics Teaching and Learning (pp. 334-370). New York, NY: MacMillan.

Schroeder, T. L \& Lester, F. K. (1989). developing understanding in mathematics via problem solving. In Trafton, P. R. \& Shulte, A. P. (Ed.), New Directions for Elementary School Mathematics. NCTM Yearbook 1989.

Shimizu, Y. (1999). Teacher education around the world - Aspects of mathematics teacher education in Japan: Focusing on teachers' roles. Journal of Mathematics Teacher Education. 2, 107.116. 